\title{
A Study on the Changes in the Appraisal Industry in the Era of the 4th Industrial Revolution - Focus on the Factors Affecting Intention to Adopt Big Data in the Appraisal Field
}

\author{
DonggunYoon ${ }^{1}$ and Jaehwan $\mathrm{Kim}^{2 *}$ \\ ${ }^{1}$ Department of Real Estate Studies, Hanyang Cyber University, 220, Wangsimni-ro, \\ Seongdong-gu, Seoul, South Korea \\ $2^{2}$ Associate Professor, Major in Real Estate Studies, Faculty of Regional \\ Development, Kongju National University. Yesan, Chungnam, South Korea \\ ${ }^{1}$ wizyoon@hycu.ac.kr, ${ }^{2 *}$ jaehwan@kongju.ac.kr
}

\begin{abstract}
The appraisal industry is the first structural change since the implementation of the public land price system in 1989. Since the environment surrounding the appraisal market has changed so far, structural adjustment from the inside is inevitable even though it was not enforced through legislation. This study aimed to identify factors that affect intention to adopt big data in the appraisal field based on the perception of values and environmental factors suggested by Paret et al., Quinn \& Baily, Elizabeth \& Michael, and Kyung, and propose a relevant guideline to institutions and corporations that consider adopting Big Data. Based on empirical analysis using SEM (structure equation modeling), the result was as follows: first, institutions and corporations that are considering adopting big data in the appraisal field should focus on improving the work process, capturing opportunities, and providing information for decision-making. Second, they must fully review internal factors of the Appraisal industry such as IT development trends and changing environment and select crucial business partnerships to gain competitiveness in the market.
\end{abstract}

Keywords: 4th industrial revolution, Real estate appraisal, Big data, Real estate industry, Internet of things

\section{Introduction}

Professor Jerry Kaplan of Stanford University, an expert in artificial intelligence, "The development of AI will destroy most of the current human work". "We cannot avoid mass unemployment" [6]. The Korea Employment Information Service analyzed the job replacement probability among the 400 major occupations in Korea through the use of artificial intelligence and robot technology.

This situation is no exception to the appraisal industry. The environment surrounding the appraisal market has changed so far. Even if it was not enforced through law enactment, structural adjustment from the inside is inevitable. I would like to suggest from the perspective that the arrival of the fourth era of the Industrial Revolution is a new opportunity, not a crisis, in terms of seeking a new direction in the appraisal industry, which is faced with the change of the internal and external situation.

Article history:

Received (February 10, 2019), Review Result (March 14, 2019), Accepted (May 13, 2019) 


\section{Literature review}

\subsection{Significance of big data}

The definition of big data is defined by various researchers. Newman defines the characteristics of big data as volume, diversity, and so on, which is beyond the capacity that conventional database systems cannot handle [4]. IBM defines Big Data Technology as meeting two or more of these $3 \mathrm{~V}$ factors. The biggest feature of big data is that it has non-uniformity such as video and image as well as video. Big data has a large data size, various types of data [2]. Data processing and analysis have to be resolved on time. As a result, you need to be able to create new value. It is defined as requiring timeliness such as real-time processing in analysis and forecasting, including both formal and unstructured data such as corporate information, web, image/video, SNS, sensor stream, etc. beyond the limit of storage, management, and analysis have.

\subsection{Status of big data}

The domestic big data market is expected to grow through the discovery of big data services in various fields such as real estate, transportation, and education. Korea Information Technology Agency (2013) expects the domestic big data market to reach about \$263 million in 2015, which will account for about $1.6 \%$ of the global market and about $\$ 900$ million in 2020. While Big Data is attracting attention with its huge data size, as its name implies, the most difficult aspect is that there are a lot of deficiencies in structuring the data. Most big data is unstructured data such as posts, videos, photos, and music that cannot be easily cataloged

\subsection{Application of big data}

For a company to adapt to the big data era, the first thing is to be armed with a mind to do data analytical management. Data analytics management means solving business problems based on data analysis. Second, companies need to innovate their businesses by digitizing business to gain a competitive advantage in the big data era.

Harim grows 200 million chickens a year in 530 direct farms and contract farms. The chickens on the farm are kept for 30 days and put in a truck at the same time. However, since the 2000s, demand has become more demanding and weighing conditions have begun. For example, a school food service company required more than 1.7 kilograms, and a franchise company required 1.5 to 1.6 kilograms. If you do not meet or exceed this weight standard, you will have to sell the chicken after it has been dismantled. Therefore, the precise weight prediction of the chickens inbreeding became very important, and Harim introduced the Internet of Things to the demonstration farm. '501 Poultry Farm' is a direct farm of Harim, raising 1 million a year in 5 farms. The farm includes infrared CCTV tracking the movements of chickens, sensors that weigh in at intervals of $1 / 10$ th of a second when the chicken is struck, sensors that measure temperature, humidity, benzene, toluene, and dust, The transmitting wireless communication equipment is installed. In this way, the Central Analysis Center has accumulated 864,000 daily data and analyzed them to be able to accurately predict the weight gain of chickens, weight distribution, and the average weight in 10-gram units.

\subsection{Public sector big data}

In Korea, we are seeking ways to implement smart government using big data in 2011. On the other hand, the "Public Data Provision and Use Revitalization Act" was enacted in July 
2013, laying the foundation for institutional devices related to support and utilization of big data [1][5].

The Ministry of Land, Transport, and Maritime Affairs (2014) has implemented 385 spatial information projects in 2014 according to national spatial information policy. In detail, there are spatial information fusion and complex business, indoor spatial information business, unification of real estate administration information and spreading of spatial information utilization business, and space information foundation business.

Meanwhile, to build a spatial data system, database construction and analysis model for population, income, weather information, real estate price, SNS and search information, which is administrative information, In the "Public Data Portal (www.data.go.kr)", which is operated by the Ministry of Government Administration and Home Affairs (MOCIE) entrusted to the Korea Information Science Promotion Agency, more than 14,000 data from over 700 public institutions are provided.

\section{Research design}

\subsection{Research model}

This study was designed to identify the factors that impact big data on strategic value recognition [1][3][4]. Based on this study, we selected products and services, management productivity, decision support, and environmental factors as independent variables considering the characteristics of the appraisal industry. The intention of introducing big data in the real estate field was selected as a dependent variable and the research model was formed as [Figure $1]$.

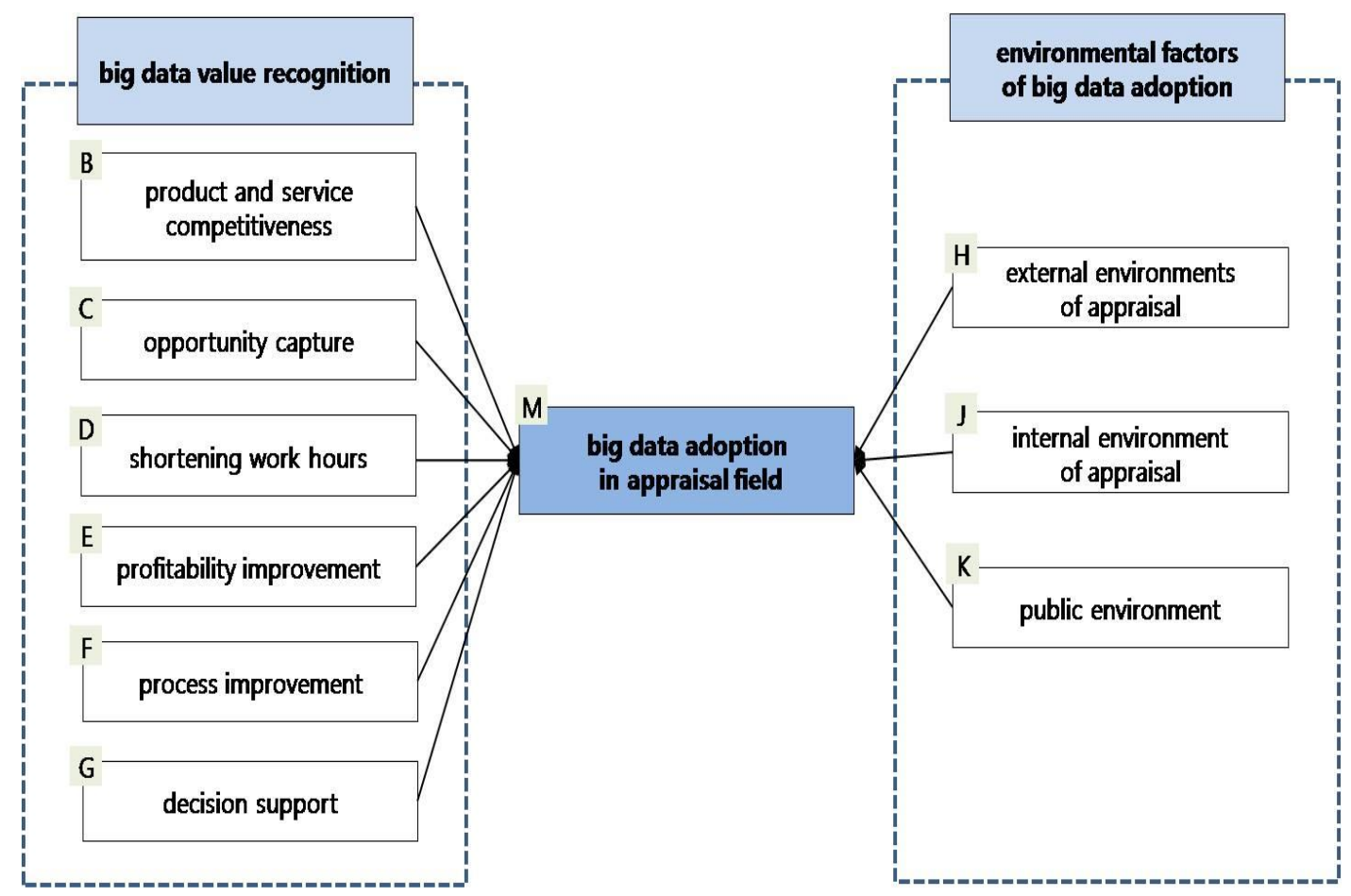

Figure1. Research model design 


\subsection{Measurement items of independent variables}

In the study, variables and detailed measurement items were selected and measured on a scale of 5 points.

Table 1. Independent variable's measurement items

\begin{tabular}{|c|c|c|}
\hline \multirow{4}{*}{$\begin{array}{c}\text { product and } \\
\text { service } \\
\text { competitiveness } \\
\text { (B) }\end{array}$} & B1 & Customized and intelligent products and services can be provided. \\
\hline & B2 & It helps improve processes for providing products and services for companies. \\
\hline & B3 & $\begin{array}{c}\text { Improve real-time coping and support capabilities for customer's product and } \\
\text { service requirements. }\end{array}$ \\
\hline & B4 & Improve real-time coping skills with product and service risk factors. \\
\hline \multirow{4}{*}{$\begin{array}{l}\text { opportunity } \\
\text { capture } \\
\text { (C) }\end{array}$} & $\mathrm{C} 1$ & Improves the ability to capture opportunities to improve business processes. \\
\hline & $\mathrm{C} 2$ & Improves the ability to capture opportunities to improve products and services. \\
\hline & $\mathrm{C} 3$ & Improves ability to capture new and new service development opportunities. \\
\hline & $\mathrm{C} 4$ & Improves ability to capture new business opportunities between businesses. \\
\hline \multirow{6}{*}{$\begin{array}{l}\text { shortening work } \\
\text { hours } \\
\text { (D) }\end{array}$} & D1 & It can shorten product and service production/distribution time. \\
\hline & D2 & Responding time to customer claims and requirements can be shortened. \\
\hline & D3 & $\begin{array}{l}\text { It can shorten the analysis and forecasting time for changes in the internal } \\
\text { environment and external environment of the company. }\end{array}$ \\
\hline & D4 & You can shorten the decision-making time of managers and managers. \\
\hline & D5 & It can shorten the development period for new services. \\
\hline & D6 & $\begin{array}{l}\text { It can shorten the development of new business models and the convergence } \\
\text { period with other fields. }\end{array}$ \\
\hline \multirow{4}{*}{$\begin{array}{l}\text { profitability } \\
\text { improvement } \\
\text { (E) }\end{array}$} & E1 & It can improve sales. \\
\hline & E2 & It can improve market share. \\
\hline & E3 & It can improve customer satisfaction. \\
\hline & E4 & It can improve returns \\
\hline \multirow{5}{*}{$\begin{array}{c}\text { process } \\
\text { improvement } \\
\text { (F) }\end{array}$} & F1 & You can improve the process of providing services. \\
\hline & $\mathrm{F} 2$ & You can improve the forecasting process. \\
\hline & F3 & Improve the decision-making process of managers and managers \\
\hline & F4 & Improve the new service development process. \\
\hline & F5 & Improve new and new business development processes. \\
\hline \multirow{3}{*}{$\begin{array}{l}\text { decision support } \\
\text { (G) }\end{array}$} & G1 & Effectively support decision-making for issues and risk responses. \\
\hline & G2 & $\begin{array}{l}\text { It can provide various information for decision-making based on social } \\
\text { phenomena and real data. }\end{array}$ \\
\hline & G3 & Various analyses and predictions are available for decision-making. \\
\hline
\end{tabular}

\subsection{Reliability and feasibility verification}

The measurement variables were analyzed to extract the constituent factors through the scale refinement process, and the direct method was adopted to simplify the factorial materialization. The selection criteria for the available measurement items in this study were: 1.0 or more for the unique value and 0.4 or more for the factor load.

As a result of the factor analysis of the independent variables, 18 items were finally adopted by removing the seven measurement items loaded in accordance with the theoretical structure. 
Table 2. Factor analysis result

\begin{tabular}{|c|c|c|c|c|c|c|c|}
\hline \multirow{2}{*}{ Division } & \multicolumn{6}{|c|}{ Component } & \multirow{2}{*}{ Cronbach $\alpha$} \\
\hline & $\mathrm{F}$ & E & $\mathrm{D}$ & G & B & $\mathrm{C}$ & \\
\hline F3 & .808 & .195 & .063 & .217 & .064 & .135 & \multirow{5}{*}{0.902} \\
\hline $\mathrm{F} 4$ & .765 & .231 & .125 & .172 & .265 & .194 & \\
\hline F5 & .762 & .329 & .195 & .156 & .225 & .085 & \\
\hline $\mathrm{F} 2$ & .672 & .130 & .268 & .212 & .161 & .252 & \\
\hline F1 & .642 & .174 & .292 & .165 & .415 & .125 & \\
\hline E2 & .105 & .891 & .089 & .076 & .191 & .084 & \multirow{4}{*}{0.899} \\
\hline E1 & .172 & .855 & .107 & .171 & .175 & .071 & \\
\hline E4 & .318 & .781 & .215 & .191 & .023 & .065 & \\
\hline E3 & .319 & .691 & .294 & .171 & .081 & .214 & \\
\hline D1 & .155 & .115 & .813 & .184 & .135 & .510 & \multirow{3}{*}{0.815} \\
\hline $\mathrm{D} 2$ & .245 & .213 & .739 & .125 & .275 & .105 & \\
\hline D3 & .154 & .398 & .624 & .281 & .061 & .331 & \\
\hline G3 & .195 & .202 & .131 & .813 & .215 & .191 & \multirow{2}{*}{0.87} \\
\hline G1 & .425 & .164 & .259 & .681 & .151 & .105 & \\
\hline B3 & .272 & .129 & .133 & .237 & .827 & .201 & \multirow{2}{*}{0.898} \\
\hline B4 & .301 & .176 & .272 & .184 & .770 & .255 & \\
\hline $\mathrm{C} 1$ & .313 & .101 & .091 & .121 & .215 & .828 & \multirow{2}{*}{0.733} \\
\hline $\mathrm{C} 4$ & .187 & .242 & .284 & .255 & .315 & .638 & \\
\hline
\end{tabular}

\subsection{The effect of big data value recognition on the adoption}

As a result of multi regression analysis, the result of [Table 3] was derived assuming that there is a linear function relationship between the value recognition of big data and the adoption.

Table 3. The regression analysis of big data values recognition and adoption

\begin{tabular}{|c|c|c|c|c|c|c|c|c|}
\hline \multirow{2}{*}{$\begin{array}{l}\text { dependent } \\
\text { variable }\end{array}$} & \multirow{2}{*}{$\begin{array}{l}\text { independent } \\
\text { variable }\end{array}$} & \multicolumn{2}{|c|}{$\begin{array}{l}\text { nonstandardizatio } \\
\text { n coefficient }\end{array}$} & \multirow{2}{*}{$\begin{array}{c}\begin{array}{c}\text { Standardizati } \\
\text { on coefficient }\end{array} \\
\text { beta }\end{array}$} & \multirow{2}{*}{$\mathrm{t}$} & \multirow{2}{*}{$\begin{array}{l}\text { significant } \\
\text { probability }\end{array}$} & \multicolumn{2}{|c|}{ conjugate statistic } \\
\hline & & B & $\begin{array}{l}\text { standard } \\
\text { error }\end{array}$ & & & & $\begin{array}{l}\text { tolerance } \\
\text { limit }\end{array}$ & VIF \\
\hline \multirow{7}{*}{$\begin{array}{l}\text { big data } \\
\text { adoption } \\
\text { in the } \\
\text { appraisal } \\
\text { field }\end{array}$} & (constant) & 1.235 & 0.551 & & 1.954 & 0.053 & & \\
\hline & $\begin{array}{c}\text { process } \\
\text { improvement }\end{array}$ & 0.583 & 0.225 & 0.397 & 2.788 & 0.005 & 0.361 & 2.879 \\
\hline & $\begin{array}{l}\text { profitability } \\
\text { improvement }\end{array}$ & -0.168 & 0.145 & -0.134 & -1.049 & 0.285 & 0.485 & 1.955 \\
\hline & $\begin{array}{l}\text { shortening } \\
\text { work hours }\end{array}$ & 0.358 & 0.185 & 0.251 & 1.865 & 0.068 & 0.445 & 2.331 \\
\hline & $\begin{array}{c}\text { opportunity } \\
\text { capture }\end{array}$ & 0.481 & 0.195 & 0.353 & 2.451 & 0.015 & 0.465 & 2.152 \\
\hline & $\begin{array}{l}\text { product and } \\
\text { service } \\
\text { competitiven } \\
\text { ess } \\
\end{array}$ & -0.103 & 0.161 & -0.085 & -0.658 & 0.552 & 0.451 & 2.225 \\
\hline & $\begin{array}{l}\text { decision } \\
\text { support }\end{array}$ & 0.357 & 0.17 & 0.131 & 1.998 & 0.042 & 0.414 & 2.312 \\
\hline
\end{tabular}


As a result of verifying the association between independent variables, the VIF of all variables was less than 10 and there were no multiple conjugates.

The results of the regression analysis were $52.5 \%$ of the explanatory power as shown in [Table 3], which was statistically significant.

\section{Conclusion}

The results of the study show that changes in perception of big data have affected the valuation agency's perception of value for big data. In other words, the introduction of big data in the field of appraisal can improve the process of business performance, and big data will be able to capture opportunities such as finding new business. This suggests that big data can produce different analysis results using various external data as well as internal data, thus enabling diverse and intelligent services to customers (the public), and improving risk and crisis management capabilities to enhance external competitiveness.

Big data is still an early stage in the field of appraisal, but it is the best technology to solve all the problems in the field of appraisal efficiently. Therefore, the use of big data in the field of appraisal, which is the current pilot test level, should be more active in public, business, and academia.

\section{References}

[1] Bokseong-su, 4th Industrial Revolution and Big Data, Information, and Communication Engineering, Chungbuk National University (2016)

[2] E. Elizabeth and P. Michael, "Electronic commerce adoption: An empirical study of small and medium US businesses," Information and Management, vol.42, no.1, (2004)

[3] O. Kazumasa, "Big data-key to the 4th industrial revolution, innovation in the global economy-3," Japan spotlight, (2016)

[4] McAfee, T. Brynjofsson, "Big data: the management revolution," Harvard Business Review, October Davenport (2006)

[5] J. B. Quinn and M. N. Bailey, "Information technology: Increasing productivity in services," Academy of Management Executive

[6] Real Estate in the Age of the Fourth Industrial Revolution, BEOS Survey 05, January (2014).

[7] Samsung Economic Research Institute, "Public data openness and corporate activities," (2013)

[8] T. Gavin, C. Rozwell, and D. Freeman, "Use the internet of things in smart buildings to achieve work-life ambiance," Gartner, May (2017) 


\section{Authors}

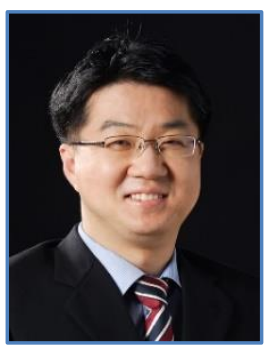

\section{Dr. Donggun, Yoon}

$\mathrm{He}$ is an associate professor of real estate at Hanyang Cyber University in South Korea. He is also an appraiser. His research interests include real estate finance, real estate investment, appraisal, and feasibility analysis.

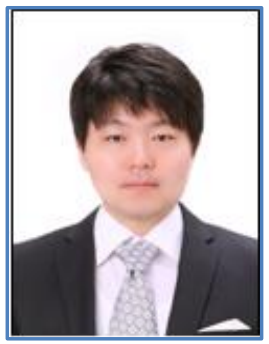

\section{Dr. Jaehwan, Kim}

$\mathrm{He}$ is an associate professor at the Department of Regional Development, Kongju National University, South Korea. His research interest is mixeduse development, feasibility study, and decision-making methodology. 
A Study on the Changes in the Appraisal Industry in the Era of the 4th Industrial Revolution - Focus on the Factors Affecting Intention to Adopt Big Data in the Appraisal Field

This page is empty by intentions. 